\title{
Biostimulant Application under Different Nitrogen Fertilization Levels: Assessment of Yield, Leaf Quality, and Nitrogen Metabolism of Tunnel-Grown Lettuce
}

\author{
Lucia Ottaiano $^{1}$, Ida Di Mola ${ }^{1} * *^{\circledR}$, Eugenio Cozzolino ${ }^{2}\left(\mathbb{D}\right.$, Christophe El-Nakhel $^{1}\left(\mathbb{D}\right.$, Youssef Rouphael ${ }^{1}(\mathbb{D}$ and \\ Mauro Mori ${ }^{1}$ \\ 1 Department of Agricultural Sciences, University of Naples Federico II, 80055 Portici, Italy; \\ lucia.ottaiano@unina.it (L.O.); christophe.elnakhel@unina.it (C.E.-N.); youssef.rouphael@unina.it (Y.R.); \\ mori@unina.it (M.M.) \\ 2 Council for Agricultural Research and Economics (CREA)-Research Center for Cereal and Industrial Crops, \\ 81100 Caserta, Italy; eugenio.cozzolino@crea.gov.it \\ * Correspondence: ida.dimola@unina.it
}

check for updates

Citation: Ottaiano, L.; Di Mola, I.; Cozzolino, E.; El-Nakhel, C.;

Rouphael, Y.; Mori, M. Biostimulant Application under Different Nitrogen Fertilization Levels: Assessment of Yield, Leaf Quality, and Nitrogen Metabolism of Tunnel-Grown Lettuce. Agronomy 2021, 11, 1613. https:// doi.org/10.3390/agronomy11081613

Academic Editor: Juan Jose Rios

Received: 2 July 2021

Accepted: 10 August 2021

Published: 13 August 2021

Publisher's Note: MDPI stays neutral with regard to jurisdictional claims in published maps and institutional affiliations.

Copyright: (c) 2021 by the authors. Licensee MDPI, Basel, Switzerland. This article is an open access article distributed under the terms and conditions of the Creative Commons Attribution (CC BY) license (https:// creativecommons.org/licenses/by/ $4.0 /)$
Abstract: Promising strategies that could aid a shift from $\mathrm{N}$-intensive agriculture to an eco-friendlier approach include the integrated use of plant-based biostimulants. To date, results about the accumulation of nitrate in green leafy vegetables due to biostimulant application are conflicting. Therefore, the current study aimed at assessing the effect of a new plant-based biostimulant, containing triacontanol (TRIA), that is claimed to reduce nitrate accumulation in leaves, based on the yield and leaf quality of lettuce grown in a plastic tunnel under different $\mathrm{N}$ conditions. The experimental design was a factorial combination of three nitrogen fertilization levels (N0, N30, and N60, corresponding to 0,30 , and $60 \mathrm{~kg} \mathrm{~N} \mathrm{ha}^{-1}$ ) and two biostimulant applications (treated with 'ILSASTIM+' $=\mathrm{YB}$ and untreated control $=\mathrm{NB}$ ). Nitrogen fertilization resulted in a $40 \%$ yield increase over N0. Biostimulant application increased the yield $21 \%$ over NB, and both improved all growth parameters. In addition, the biostimulant had a positive effect on color and Soil Plant Analysis development (SPAD) index, thus enhancing the qualitative aspect. Interestingly, biostimulant application boosted nitrogen use efficiency with a $23 \%$ increase over untreated plants. The use of biostimulant proved to be suitable to be applied in a sustainable strategy of production and quality improvement.

Keywords: nitrate; plant-derived amino acids; Fabaceae enzymatic hydrolysis; Lactuca sativa L.; NUE; nutritional quality

\section{Introduction}

Currently, the challenge in agricultural systems is to increase their production to meet the growing global demand for food [1]; in order to reach this objective, farmers often increase the use of synthetic nitrogen $(\mathrm{N})$ fertilizers. However, nitrogen overuse does not always correspond to a yield increase, indeed, it often causes decreases in $\mathrm{N}$ uptake and use by the plant, thus affecting yield and consequently profit margins for farmers. Ronga et al. [2] observed a reduction in nitrogen use efficiency (NUE) of tomato plants subjected to high nitrogen levels, as did Djidonou et al. [3], but in different experimental conditions. In previous research, we also observed a nitrogen use decrease when nitrogen dose increased in both spinach and lamb's lettuce [4]. In addition, the overuse of nitrogen fertilizer can have a detrimental impact on the environment, due to nitrogen leaching and/or greenhouse gas emission increases [5,6]. Finally, unbalanced nitrogen use can also become dangerous for human health, when it occurs in green leafy vegetables, which have a genetic predisposition to accumulate nitrate in leaf tissues. Nevertheless, nitrate accumulation in some crops (lettuce, rocket, spinach) is an undesirable qualitative trait with which, after the intake into the human body through diet, nitrate is reduced into nitrite and it can cause methemoglobinemia, and is particularly dangerous to children [7-9]. 
Promising strategies that could aid the shift from $\mathrm{N}$-intensive agriculture to a ecofriendlier approach that reduces the use of $\mathrm{N}$ fertilizers while simultaneously increasing nitrogen use efficiency (NUE) and yields include the integrated use of non-chemical plant biostimulants (PBs) in cropping systems [10]. PBs include several natural substances with bioactive properties; they present many mechanisms of action and positively affect crop growth and yield. Particularly, previous studies highlighted their capacity to enhance maize growth [11], spinach morphology and physiology [12], and yield and product quality of tomato [13] and several green leafy vegetables, like baby lettuce [14] and rocket [15]. In addition, many studies also reported PBs' capacity to improve tolerance to saline stresses in maize [16], food hemp [17], and zucchini [18], other than tolerance to heat stress [19]. Moreover, they are also able to improve nitrogen use efficiency, reducing inputs and modifying nitrogen metabolism [20]. A recent study highlighted that PBs, principally commercial legume-derived protein hydrolysate (LDPH), can potentially act on reducing nitrate accumulation in the leaves of some green leafy vegetables [21]. A similar effect was recorded by Cozzolino et al. [22] in plants treated with tropical plant extract (TPE), which showed a lower value of nitrate in lettuce leaves with respect to untreated plants. Instead, in other previous research, we found that a variable increase in leaf nitrate content occurred in several green leafy vegetables: baby lettuce treated by seaweed extract (SwE) and tropical plants, as well as LDPH [14]; rocket treated with TPE and LDPH [15]; spinach and lamb's lettuce sprayed with LDPH [4]. Nevertheless, biostimulants remain a valid eco-sustainable approach in order to reduce the use of chemical fertilizer without reducing production and yield quality. On the other hand, their capacity to improve NUE is certainly one of the most important reasons for their spread in the market, considering economic and environmental motives [23].

The reduction in $\mathrm{N}$ inputs in leafy vegetables is very important, both for containing the phenomenon of nitrate accumulation in leaves and for reducing the economic and environmental impacts of fertilization. Among these crops, lettuce (Lactuca sativa L.) has a relevant role in the world market, with Italy as a leader in Europe, with large areas cultivated with lettuce [24]. Lettuce plays a key role in the Mediterranean diet for its organoleptic properties and its high content of health-promoting metabolites, such as: carotenoids, chlorophylls, macro- and trace elements, phenolics, and vitamins and a low content of fat $[25,26]$. These properties can vary in quantity and quality, depending on several pre-harvest factors, including agronomic practices [27].

Based on the abovementioned considerations, the aim of the current study was to assess the effect of a new $\mathrm{PB}$, with respect to their characteristics of reducing nitrate accumulation in leaves and boosting yield and leaf quality, on lettuce grown in a plastic tunnel under different $\mathrm{N}$ conditions. This biostimulant, as declared by the producer, has the characteristic of reducing nitrate accumulation in plant tissue; in particular, it contains triacontanol (TRIA), which is a long-chain primary alcohol able to alter metabolism and regulate various physiological and biochemical processes under different conditions [28]. This biostimulant stimulates biomass formation and elicits the action of the enzymes regulating nitrogen use (nitrate reductase, nitrite reductase, GS, and GOGAT), thus reducing excess nitrate in vegetal tissues, a main feature of leafy green vegetables. In addition, it can improve vegetable quality and increase resistance to climatic stresses. In other studies, it was found that TRIA can be applied at any growth stage, and it stimulates growth processes [29], increasing water and nutrient uptake [30] and enhancing photosynthesis, nitrogen fixation, synthesis of proteins, amino acids, and activity of antioxidant enzymes in plants [31-35]. Thus, the obtained results can offer more insight into combining the best nitrogen fertilization with biostimulant application in order to upgrade lettuce production management. 


\section{Materials and Methods}

\subsection{Experimental Design, Growing Conditions, and Treatments}

The experiment was carried out in a plastic tunnel during winter 2020 at the experimental site "Gussone Park" of the Department of Agricultural Sciences in Portici (Naples, Italy). The soil was classified as sandy loam texture based on the United States Department of Agriculture (USDA) soil classification, with $\mathrm{pH} 7.4,2.5 \%$ organic matter (O.M.), $0.9 \%$ total nitrogen (N), $252.6 \mathrm{mg} \mathrm{kg}^{-1} \mathrm{P}_{2} \mathrm{O}_{5}$, and $490.9 \mathrm{mg} \mathrm{kg}^{-1}$ of $\mathrm{K}_{2} \mathrm{O}$. The lettuce (Lactuca sativa L.) cultivar "Jumper" (Gautier Seed Cesena, Italy), characterized by a semi-closed head with medium brilliant green leaves, was the chosen test crop. The lettuce plants were transplanted on January 24 (at the 3 true leaf stage) in double rows with a plant density of 11.1 plants $\mathrm{m}^{-2}$. A photo-selective yellow mulching film was placed by hand before the transplant. The experimental design was a factorial combination of three nitrogen fertilization levels $(\mathrm{N})$ and two biostimulant applications (B) distributed in a randomized complete block design. Each treatment was replicated three times in a total of 18 plots; each plot was $1.2 \times 3 \mathrm{~m}$.

The three $\mathrm{N}$ fertilization levels were: N0 $\left(0 \mathrm{~kg} \mathrm{ha}^{-1}\right), \mathrm{N} 30\left(30 \mathrm{~kg} \mathrm{~N} \mathrm{ha}^{-1}\right)$, and N60 $\left(60 \mathrm{~kg} \mathrm{~N} \mathrm{ha}^{-1}\right)$ : not fertilized, sub-optimal, and optimal dose, respectively; $\mathrm{N}$ was added as ammonium nitrate $(26 \%)$ in a single application during the pre-transplantation stage. The two biostimulant treatments were: treated (YB) and untreated control (NB). The used plantderived biostimulant was "ILSASTIM+" produced by ILSA S.p.A. (Arzignano, Vicenza, Italy); it is obtained through enzymatic hydrolysis of Fabaceae tissues, including peas, beans, soybeans, alfalfa, etc. Its composition is $1 \%$ total nitrogen and $6 \%$ amino acids, of which $1.5 \%$ is free amino acids, $10 \%$ organic carbon, sulfurated compounds, and $8 \mathrm{mg} \mathrm{kg}^{-1}$ of natural TRIA [34]. TRIA is a compound commonly present in Fabaceae [35] and it acts as plant growth regulator [36]; in particular, Islam et al. [37] reported the effect of triacontanol on the physiological and biochemical characters of several plant species grown under salt stress conditions.

The biostimulant was sprayed on leaves at a concentration of $3 \mathrm{~mL} \mathrm{~L}^{-1}$ in three applications during the whole growing season; the first application was carried out on February 5, the other two after 14 and 28 days, at the 42,45 , and 48 stage of the BBCH scale, corresponding to $20 \%, 50 \%$, and $80 \%$ of the expected head size, respectively.

\subsection{Yield and Morphological Parameter Measurements and Quality Analysis Samplings}

On March 17, lettuce plants were harvested. Nine plants of the central row per replicate were cut when they reached commercial weight; the external leaves were removed and then each head was weighed in order to determine marketable yield, expressed as $\mathrm{kg} \mathrm{m}^{-2}$. A sample per replicate was oven-dried at $70^{\circ} \mathrm{C}$ until a constant weight, and subsequently the dry matter (DM) percentage was calculated and the dry material was used to determine nitrate content. For three heads per replicate, growth parameters (diameter and number of leaves) were determined. Finally, a sub-sample per replicate was collected and stored at $-80{ }^{\circ} \mathrm{C}$ in order to determine the bioactive compound content and antioxidant activities.

\subsection{Leaf Color, Pigment Content, and SPAD Index Measurement}

For ten undamaged leaves of lettuce per experimental unit (i.e., replicate), color CIELAB parameters $\left(\mathrm{L}^{*}\right.$ brightness, $\mathrm{a}^{*}$, and $\mathrm{b}^{*}$ ) were measured by a Minolta Chromameter (CR-300, Minolta Camera Co. Ltd., Tokyo, Japan), at the center of the upper leaf surface (between the midrib and the leaf margin).

In addition, for ten fully expanded leaves per replicate, the Soil Plant Analysis development (SPAD) index was also measured by a chlorophyll meter (Minolta SPAD-502, Tokyo, Japan).

For fresh frozen samples, pigment (chlorophyll $a$, chlorophyll $b$, and total chlorophyll, as well as carotenoids) measurements were performed; the chlorophyll content of leaves was determined according to the method described by Lichtenhaler and Buschman [38], by measuring the absorbance of the solutions at 470,662 , and $647 \mathrm{~nm}$ for carotenoids, 
chlorophyll a, and chlorophyll b, respectively. Total chlorophylls were calculated as the sum of chlorophyll a and b. The absorbance was measured through a Hach DR 2000 spectrophotometer (Hach Co., Loveland, CO, USA).

\subsection{Antioxidant Activities and Bioactive Compound Measurements}

For freeze-dried samples of lettuce leaves, hydrophilic and lipophilic antioxidant activity (HAA and LAA, respectively), total phenols, and total ascorbic acid content (TAA) were assessed. HAA and LAA were determined using the DMPD [39] and ABTS [40] methods, respectively. The reduction in absorbance of the solutions obtained with the two methods was measured by UV-Vis spectrophotometry with an ONDA V-10 Plus (Giorgio Bormacs.r.l, Carpi, Italy), at 505 and $734 \mathrm{~nm}$, respectively, using ascorbate and Trolox external standard calibration curves for HAA and LAA, respectively. Total phenols were also measured by a spectrophotometer and the absorbance solution was detected at $765 \mathrm{~nm}$, according to the Singleton et al. method [41]. Total ascorbic acid was determined spectrophotometrically according to the protocol of Kampfenkel et al. [42] and the solution absorbance was measured at $525 \mathrm{~nm}$.

\subsection{Leaf Nitrate Content and Nitrogen Use Efficiency}

Nitrate content of leaves was determined for oven-dried samples, by a Foss FIAstar 5000 continuous flow analyzer (FOSS analytical Denmark), based on the colorimetric method. As reported by Di Mola et al. [4], nitrogen use efficiency (NUE) was determined as the ratio between yield and $\mathrm{N}$ application dose plus the available nitrogen in the soil, and it was expressed as ton $\mathrm{kg}^{-1}$.

\subsection{Statistical Analysis}

All data were subjected to two-way ANOVA using the SPSS 22 software package (Chicago, IL, USA). Means were separated utilizing Duncan's multiple range test that was performed at the 0.05 significance level.

\section{Results}

\subsection{Marketable Yield and Morphological Parameters}

No interaction between nitrogen and biostimulant application was registered for marketable yield. Both factors significantly affected lettuce marketable yield, which exhibited a significant increase (about $40 \%$ ) with the increased nitrogen dose but without differences between sub-optimal and optimal doses (Figure 1). Additionally, biostimulant application boosted lettuce marketable yield with a 21\% increase over untreated control (Figure 1).

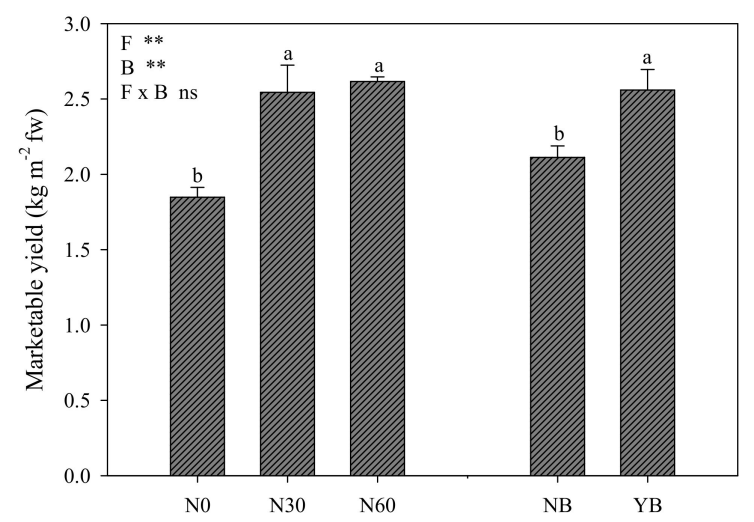

Figure 1. Lettuce marketable yield affected by nitrogen fertilization levels $(\mathrm{N} 0=0, \mathrm{~N} 30=30$, and $\mathrm{N} 60=60 \mathrm{~kg} \mathrm{ha}^{-1}$ ) and biostimulant application (NB: not treated, YB: treated). Different letters above bars indicate significant mean differences according to Duncan's multiple range tests $(p \leq 0.05)$. Vertical bars indicate $\pm \mathrm{SE}$ of means. NS, ${ }^{*},{ }^{* *}$, not significant or significant at $p \leq 0.05$ and 0.01 . $\mathrm{fw}=$ fresh weight. 
The results regarding morphological parameters and yield are reported in Table 1 . The interaction between $\mathrm{N}$ fertilization level and biostimulant application was never significant, while both factors significantly affected all parameters, except leaf DM percentage, which was influenced only by biostimulant application.

Table 1. Effects of nitrogen fertilization $\left(\mathrm{N} 0=0, \mathrm{~N} 30=30\right.$, and $\left.\mathrm{N} 60=60 \mathrm{~kg} \mathrm{ha}^{-1}\right)$ levels and biostimulant application (NB: not treated, YB: treated) on fresh weight, diameter, leaf number, and leaf dry matter (DM) of lettuce.

\begin{tabular}{ccccc}
\hline Treatments & $\begin{array}{c}\text { Fresh Weight } \\
\text { g head }^{-1}\end{array}$ & $\begin{array}{c}\text { Head Diameter } \\
\mathbf{c m}\end{array}$ & $\begin{array}{c}\text { Leaf Nb } \\
\text { n head }\end{array}$ & $\begin{array}{c}\text { Leaf DM } \\
\%\end{array}$ \\
\hline Fertilization & & & & \\
N0 & $205.29^{\mathrm{b}}$ & $24.25^{\mathrm{b}}$ & $33.0^{\mathrm{b}}$ & 4.83 \\
N30 & $282.69^{\mathrm{a}}$ & $25.67^{\mathrm{a}}$ & $44.5^{\mathrm{a}}$ & 4.73 \\
N60 & $290.64^{\mathrm{a}}$ & $25.50^{\mathrm{a}}$ & $43.5^{\mathrm{a}}$ & 4.90 \\
Biostimulants & $234.73^{\mathrm{b}}$ & $24.56^{\mathrm{b}}$ & $38.33^{\mathrm{b}}$ & $4.61^{\mathrm{b}}$ \\
NB & $284.36^{\mathrm{a}}$ & $25.72^{\mathrm{a}}$ & $42.33^{\mathrm{a}}$ & $5.02^{\mathrm{a}}$ \\
YB & $* *$ & $* *$ & $*$ & NS \\
Significance & $* *$ & $* *$ & $* *$ & $*$ \\
Fertilization (F) & $\mathrm{NS}$ & $\mathrm{NS}$ & $\mathrm{NS}$ & $\mathrm{NS}$ \\
Biostimulants (B) & & & & \\
F $\times$ B & & & & \\
\hline
\end{tabular}

$\mathrm{NS}^{*}, * *$, not significant or significant at $p \leq 0.05$ and 0.01 . Different letters within each column indicate significant differences according to Duncan's multiple range test $(p \leq 0.05)$.

In particular, both fertilized treatments showed values significantly higher than N0 plants (about $+40 \%$ ), and without a significant difference between them. Similarly, for head diameter and number of leaves at $30 \mathrm{~kg} \mathrm{ha}^{-1}$ of nitrogen, the highest values were also recorded, with an average increase in the two fertilized treatments over the unfertilized samples of about $6 \%$ and $35 \%$, respectively. Interestingly, the biostimulant significantly increased all growth parameters: $21 \%, 5 \%, 10 \%$, and $9 \%$ compared to untreated plants for fresh weight, head diameter, leaf number, and leaf dry matter, respectively).

\subsection{Leaf Color, Pigment Content, and SPAD Index}

Similarly, no interaction $(\mathrm{N} \times \mathrm{B})$ was found for the SPAD index and color components, but only the main effects of the two factors; the data are reported in Table 2. The SPAD index showed a linear increase when the nitrogen dose increased: $+14 \%$ and $+17 \%$ over unfertilized plants for N30, and N60, respectively. The biostimulant application also elicited an increase in SPAD of about $9 \%$ with respect to untreated plants (Table 2).

Table 2. Effects of nitrogen fertilization levels ( $N 0=0, \mathrm{~N} 30=30$, and $\mathrm{N} 60=60 \mathrm{~kg} \mathrm{ha}{ }^{-1}$ ) and biostimulant applications (NB: not treated, YB: treated) on Soil Plant Analysis development (SPAD) index and leaf color parameters of lettuce.

\begin{tabular}{ccccc}
\hline Treatments & SPAD Index & $\mathbf{L}^{*}$ & $\mathbf{a}^{*}$ & $\mathbf{b}^{*}$ \\
\hline Fertilization & & & & \\
N0 & $33.77^{\mathrm{c}}$ & $48.21^{\mathrm{c}}$ & -10.30 & 29.03 \\
N30 & $38.54^{\mathrm{b}}$ & $49.55^{\mathrm{b}}$ & -10.02 & 28.60 \\
N60 & $39.54^{\mathrm{a}}$ & $50.64^{\mathrm{a}}$ & -10.02 & 27.92 \\
Biostimulants & & & & \\
NB & $35.73^{\mathrm{b}}$ & $47.85^{\mathrm{b}}$ & $-9.74^{\mathrm{b}}$ & $27.52^{\mathrm{b}}$ \\
YB & $38.83^{\mathrm{a}}$ & $51.08^{\mathrm{a}}$ & $-10.48^{\mathrm{a}}$ & $29.50^{\mathrm{a}}$ \\
Significance & $* *$ & $* *$ & NS & NS \\
Fertilization (F) & $* *$ & $* *$ & $* *$ & NS \\
Biostimulants (B) & NS & NS & NS & NS \\
F $\times$ B & & & &
\end{tabular}

$\mathrm{NS}^{*},{ }^{* *}$, not significant or significant at $p \leq 0.05$ and 0.01 . Different letters within each column indicate significant differences according to Duncan's multiple range test $(p \leq 0.05)$. 
The color parameters were less affected by nitrogen dose, indeed, only $\mathrm{L}^{*}$ was significantly modulated by nitrogen dose, which yielded an increase at the N30 dose of around $3 \%$ more than N0 and the increase reached 5\% with the N60 treatment (Table 2), whereas all three parameters were increased by biostimulant application: $7 \%, 8 \%$, and $7 \%$, for $\mathrm{L}^{*}, \mathrm{a}^{*}$, and $b^{*}$, respectively.

Lettuce leaf pigments (chlorophylls and carotenoids) were only slightly affected by the experimental factors. Indeed, only chlorophyll a and total chlorophylls increased when $\mathrm{N}$ level increased, reaching the highest significant values with N60, which were $24 \%$ and $22 \%$ more than the mean value of $\mathrm{N} 0$ and N30, respectively (Table 3).

Table 3. Effects of nitrogen fertilization levels ( $N 0=0, \mathrm{~N} 30=30$, and $\mathrm{N} 60=60 \mathrm{~kg} \mathrm{ha}^{-1}$ ) and biostimulant applications (NB: not treated, YB: treated) on chlorophyll a, chlorophyll b, total chlorophylls, and carotenoids of lettuce.

\begin{tabular}{|c|c|c|c|c|}
\hline Treatments & $\begin{array}{c}\text { Chlorophyll a } \\
\mathrm{mg} \mathrm{g}^{-1} \mathrm{fw}\end{array}$ & $\begin{array}{l}\text { Chlorophyll b } \\
\mathrm{mg} \mathrm{g}^{-1} \mathrm{fw}\end{array}$ & $\begin{array}{c}\text { Total } \\
\text { Chlorophylls } \\
\text { mg g }^{-1} \mathrm{fw}\end{array}$ & $\begin{array}{c}\text { Carotenoids } \\
\mu \mathrm{g} \mathrm{g}^{-1} \mathrm{fw}\end{array}$ \\
\hline \multicolumn{5}{|l|}{ Fertilization } \\
\hline N0 & $0.551^{\mathrm{b}}$ & 0.213 & $0.764^{\mathrm{b}}$ & 333 \\
\hline N30 & $0.591^{\mathrm{b}}$ & 0.222 & $0.813^{\mathrm{b}}$ & 295 \\
\hline N60 & $0.707^{\mathrm{a}}$ & 0.254 & $0.960^{\mathrm{a}}$ & 265 \\
\hline \multicolumn{5}{|l|}{ Biostimulants } \\
\hline NB & 0.635 & 0.237 & 0.871 & 299 \\
\hline $\mathrm{YB}$ & 0.598 & 0.222 & 0.820 & 297 \\
\hline \multicolumn{5}{|l|}{ Significance } \\
\hline Fertilization (F) & $*$ & NS & $*$ & NS \\
\hline Biostimulants (B) & NS & NS & NS & NS \\
\hline $\mathrm{F} \times \mathrm{B}$ & NS & NS & NS & NS \\
\hline
\end{tabular}

$\overline{\mathrm{NS}},{ }^{*}, * *$, not significant or significant at $p \leq 0.05$, respectively. Different letters within each column indicate significant differences according to Duncan's test $(p \leq 0.05)$. fw $=$ fresh weight.

\subsection{Antioxidant Activities and Bioactive Compounds}

Antioxidant activities and total ascorbic acid were affected only by nitrogen fertilization. No effect of biostimulant application was found regarding these parameters. In particular, total phenols were not influenced by experimental factors (Table 4). LAA, HAA, and TAA linearly decreased with increasing $\mathrm{N}$ doses, reaching the lowest values with N60, while N30 was not significantly different from N0. In particular, the N60 treatment engendered a decrease with respect to the mean value of N0 and N30 of $22 \%, 12 \%$, and $36 \%$ for LAA, HAA, and TAA, respectively (Table 4 ).

Table 4. Effects of nitrogen fertilization levels $\left(\mathrm{N} 0=0, \mathrm{~N} 30=30\right.$, and $\left.\mathrm{N} 60=60 \mathrm{~kg} \mathrm{ha}^{-1}\right)$ and biostimulant applications (NB: not treated, YB: treated) on lipophilic (LAA) and hydrophilic (HAA) antioxidant activities, total phenols, and total ascorbic acid (TAA) of lettuce.

\begin{tabular}{|c|c|c|c|c|}
\hline Treatments & $\begin{array}{c}\text { LAA } \\
\text { mMTrolox eq. } \\
100 \mathrm{~g}^{-1} \mathrm{dw}\end{array}$ & $\begin{array}{c}\text { HAA } \\
\text { mM AA eq. } 100 \\
\mathrm{~g}^{-1} \mathrm{dw}\end{array}$ & $\begin{array}{l}\text { Total Phenols } \\
\text { mg Gallic Acid } \\
\text { eq. } \mathrm{g}^{-1} \mathrm{dw}\end{array}$ & $\begin{array}{c}\text { TAA } \\
\mathrm{mg} \mathrm{g}^{-1} \mathbf{f w}\end{array}$ \\
\hline \multicolumn{5}{|l|}{ Fertilization } \\
\hline N0 & $9.64^{\mathrm{a}}$ & $5.96^{\mathrm{a}}$ & 1.65 & $28.34^{\mathrm{a}}$ \\
\hline N30 & $8.60^{a b}$ & $5.65^{\mathrm{a}}$ & 1.46 & $22.39 \mathrm{ab}$ \\
\hline N60 & $7.13^{b}$ & $5.12^{b}$ & 1.40 & $17.10^{\mathrm{b}}$ \\
\hline \multicolumn{5}{|l|}{ Biostimulants } \\
\hline NB & 8.43 & 5.34 & 1.58 & 22.89 \\
\hline YВ & 8.49 & 5.81 & 1.42 & 22.34 \\
\hline
\end{tabular}


Table 4. Cont.

\begin{tabular}{|c|c|c|c|c|}
\hline Treatments & $\begin{array}{c}\text { LAA } \\
\text { mMTrolox eq. } \\
100 \mathrm{~g}^{-1} \mathrm{dw}\end{array}$ & $\begin{array}{c}\text { HAA } \\
\text { mM AA eq. } \\
100 \mathrm{~g}^{-1} \mathrm{dw}\end{array}$ & $\begin{array}{l}\text { Total Phenols } \\
\text { mg Gallic Acid } \\
\text { eq. } \mathbf{g}^{-1} \mathbf{d w}\end{array}$ & $\begin{array}{c}\text { TAA } \\
\mathrm{mg} \mathrm{g}^{-1} \mathbf{f w}\end{array}$ \\
\hline $\begin{array}{c}\text { Significance } \\
\text { Fertilization (F) }\end{array}$ & $*$ & $* *$ & NS & $*$ \\
\hline Biostimulants (B) & NS & NS & NS & NS \\
\hline $\mathrm{F} \times \mathrm{B}$ & NS & NS & NS & NS \\
\hline
\end{tabular}

$\mathrm{NS}^{*}, * *$, not significant or significant at $p \leq 0.05$ and 0.01 . Different letters within each column indicate significant differences according to Duncan's test $(p \leq 0.05) . \mathrm{dw}=$ dry weight; $\mathrm{fw}=$ fresh weight.

\subsection{Nitrogen Metabolism: Leaf Nitrate Content and Nitrogen Use Efficiency}

The nitrate content in lettuce leaves was significantly affected only by nitrogen fertilization level, which favored the nitrate accumulation in leaf tissue of plants with N30 and N60 treatments (Figure 2). Interestingly, the biostimulant application did not modulate nitrate accumulation, indeed, the values of treated and untreated plants were not statistically different (Figure 2).

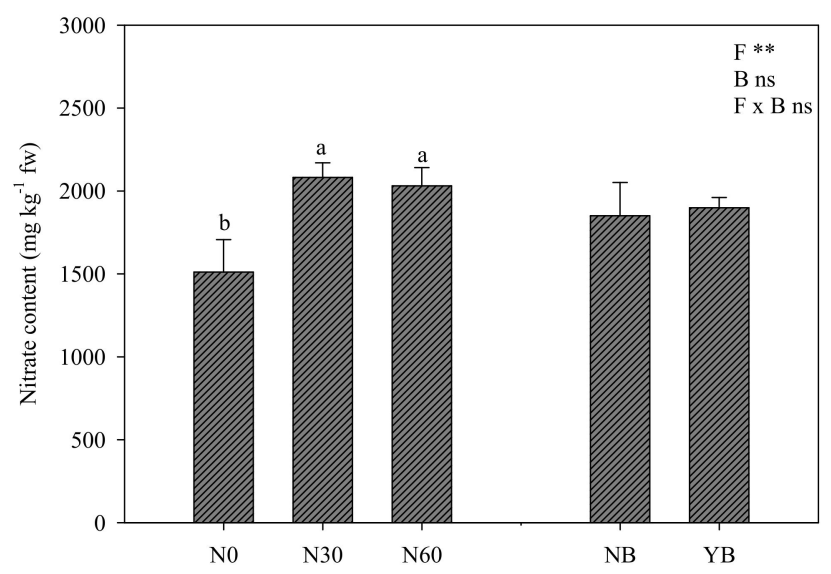

Figure 2. Nitrate content of lettuce affected by nitrogen fertilization levels $(\mathrm{N} 0=0, \mathrm{~N} 30=30$, and $\mathrm{N} 60=60 \mathrm{~kg} \mathrm{ha}^{-1}$ ) and biostimulant application (NB: not treated, YB: treated). Different letters above bars indicate significant mean differences according to Duncan's multiple range tests $(p \leq 0.05)$. Vertical bars indicate \pm SE of means. NS, ${ }^{*},{ }^{* *}$, not significant or significant at $p \leq 0.05$ and 0.01 . $\mathrm{fw}=$ fresh weight.

The nitrogen use efficiency significantly decreased when the nitrogen dose increased, with $-37 \%$ and $-58 \%$ for N30, and N60 with respect to the N0 treatment, respectively (Figure 3). Notably, biostimulant application boosted NUE with a $23.2 \%$ increase over untreated plants (Figure 3). 


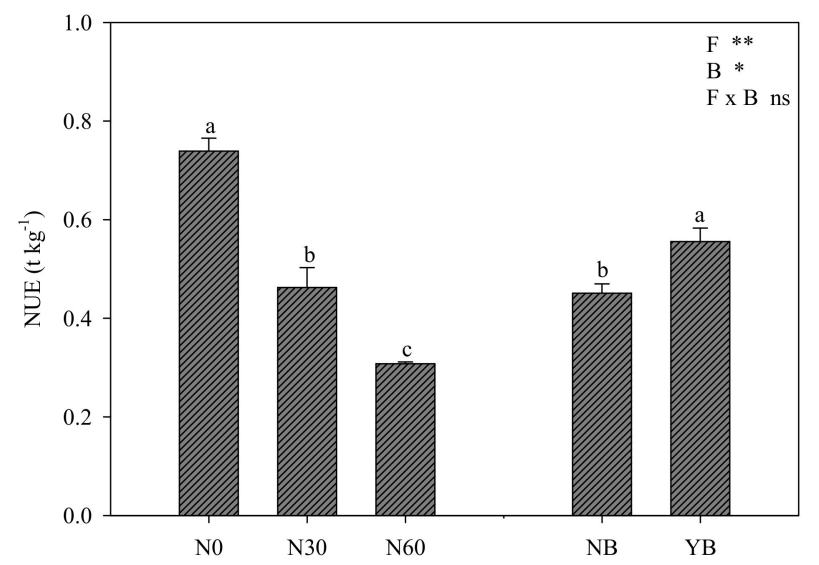

Figure 3. Nitrogen use efficiency (NUE, calculated as ratio between fresh yield and $\mathrm{N}$ application dose plus the available nitrogen in the soil) of lettuce affected by nitrogen fertilization levels (N0 $=0$, $\mathrm{N} 30=30$, and N60 $=60 \mathrm{~kg} \mathrm{ha}^{-1}$ ) and biostimulant application (NB: not treated, YB: treated). Different letters above bars indicate significant mean differences according to Duncan's multiple range tests $(p \leq 0.05)$. Vertical bars indicate $\pm \mathrm{SE}$ of means. NS, ${ }^{*},{ }^{* *}$, not significant or significant at $p \leq 0.05$ and 0.01 .

\section{Discussion}

Nitrogen is a crucial element for the optimal growth and production of any crop, but due to the possible environmental implications of its incorrect application, the management of this element by farmers is a fundamental goal, and even more important in green leafy vegetables which have a natural predisposition to accumulate nitrate in leaf tissue. In order to avoid these problems, an eco-sustainable approach is the integrated use of non-chemical PBs [10]. Our results confirmed the ability of a biostimulant to increase the growth (head fresh weight) and marketable yield of lettuce grown under greenhouse conditions, and to elicit an increase in leaf dry matter. Indeed, several studies reported the beneficial effects of the application of different biostimulants on lettuce yield, such as that by Kopta et al. [43], who found an increase in fresh weight of romaine lettuce treated with a mixed preparation of bacteria and algae both in the spring and summer cycle. Equally, Cristofano et al. [44] found an increase in lettuce crisp head shoot fresh yield when treated with PBs. Additionally, Khan et al. [45] investigated the response of lettuce to the application of six concentrations of L-methionine (from 0.02 to $2200 \mathrm{mg} \mathrm{L}^{-1}$ as control and highest concentration, respectively) and they found a positive effect of a low concentration of this amino acid on lettuce growth, due to the improvement of several physiological parameters.

However, other researchers specifically investigated the effect of triacontanol on several crops; Singh et al. [29] reported a positive effect of TRIA at different concentrations (until $10^{-6} \mathrm{M}$ ) on growth parameters of ginger, and Kapitsimadi et al. [46] found an increase in yield of several horticultural crops (tomato, sweet pepper, sugar beet, cotton, and potato). Ertani et al. [16] also tested an alfalfa plant (Medicago sativa L.) hydrolysatebased biostimulant (EM) containing triacontanol on maize plants subjected to different salt stress levels, comparing EM to exogenous triacontanol (TRIA), and they found a positive effect of EM or TRIA on root and leaf fresh weight, both under non-saline and saline stress conditions. Ertani et al. [16] suggested that the positive effect of EM and TRIA on plant growth is due to stimulation of $\mathrm{N}$ assimilation, in line with Knowles and Ries [47]; indeed, higher $\mathrm{N}$ uptake could enhance photosynthesis and translocation of photosynthates and other metabolites to the sinks, with consequently greater yield.

On the other hand, biostimulants are known to be able to improve nitrogen metab -olism $[4,48]$. Indeed, the improved state of plants sprayed with "ILSASTIM+" is also highlighted by higher values of the SPAD index; in these plants, foliar application of the biostimulant yielded a $9 \%$ increase with respect to untreated plants. A similar response 
was recorded by Ertani et al. [16], in maize, with 14\% and 8\% increases over control plants, for EM- and TRIA-treated plants, respectively. In addition, the SPAD index increase with biostimulant application is coherent with Cristofano et al.'s [44] study, where an increase in these values was registered when lettuce was treated with PHs of vegetal origin. The positive effect of the "ILSASTIM+" biostimulant on nitrogen metabolism also resulted in an improvement of nitrogen use efficiency, which was higher in plants treated with biostimulant $(+23 \%)$. However, the interesting part is that the foliar application of this biostimulant had no influence on nitrate content in leaf tissues, which was not significantly different from the value of untreated plants (1899 vs. $1851 \mathrm{mg} \mathrm{kg}^{-1}$, respectively). The nitrate values of both treated and untreated plants were under a fixed limit by the EC, corresponding to $5000 \mathrm{mg} \mathrm{kg}^{-1}$ for lettuce cultivated in a protected environment and harvested between October 1 and March 31 [49].

Our findings are not strictly in line with what was indicated by the producer about the ability of "ILSASTIM+" to reduce nitrate accumulation in leaves and fruits, because the nitrate content of treated plants was not lower than that of control plants. However, the absence of overaccumulation of nitrate in treated plants is interesting. Indeed, to date, contrasting results have been obtained regarding the effect of biostimulants on nitrate accumulation in vegetal tissues, mainly leaf tissues. Some authors found that they are useful to reduce nitrate accumulation [21,22], but in previous research we highlighted a nitrate increase in leaves $[4,14,15]$. The different behavior with respect to the indication of the producer could be due to the specific growth conditions. Indeed, the lettuce was cultivated during the winter season, characterized by a low radiation level that reduces nitrate reductase activity, consequently increasing the nitrate content in the leaves. This condition was probably exacerbated by cultivation under the plastic tunnel, which further reduced the incident radiation. Indeed, in two of our previous studies on lettuce (cv. Cambria) cultivated under different saline stress conditions with irrigation water treatment (from no stress $E C=0.7 \mathrm{dS} \mathrm{m}^{-1}$ to high stress $E C=7.2 \mathrm{dS} \mathrm{m}^{-1}$ ) in winter [50] and spring [51], we found a higher value of nitrate content in leaves of winter lettuce than that of spring lettuce: 2400 vs. $1900 \mathrm{mg} \mathrm{kg}^{-1}$ (mean value of two years in each experiment). These results confirm that, regardless of genetic traits, the environmental conditions dominate the nitrate accumulation in leaves. Therefore, we can assume that the effect of the growth conditions (winter period) overcame the PB's capacity to contain nitrate, but it was still able to keep the treated plants' levels the same as the untreated plants. This ability can be attributed to the presence of TRIA, which is involved in nitrate reductase activity and protein synthesis [52].

Nitrate reductase (NR) and nitrite reductase (NiR) are enzymes involved in the twostep reduction of nitrate to ammonium, which is then incorporated into organic compounds thanks to the activity of the enzyme glutamine synthetase (GS) [53,54]. In successive steps, GS, in association with other enzymes, produces glutamate (Glu) which is the substrate to form aspartate (Asp) [54]. Aspartate is the precursor for several essential amino acids involved in osmotic regulation; in addition, it represents the connection between the nitrogen and carbon metabolic pathways [55]. Schiavon et al. [48] tested the effects of an alfalfa-based biostimulant on the growth, productivity, and nitrogen use efficiency of maize plants, by investigating the activity and gene expression of enzymes that are involved in nitrogen and carbon metabolisms. They found that this biostimulant, which has an origin matrix (Leguminosae) similar to the biostimulant used in our test, boosted the activity of NR and NiR, resulting in a significant reduction in nitrate content in leaf tissue. More specifically, Islam and Mohammad [56] reported research where the application of triacontanol showed a positive effect on NR activity.

Despite the effect of this biostimulant on nitrogen metabolism, it partially affected the other parameters linked to $\mathrm{N}$ availability; indeed, foliar application of the biostimulant yielded a $7 \%, 8 \%$, and $7 \%$ increase for $L^{*}, a^{*}$, and $b^{*}$, respectively, but it did not affect green pigments and carotenoids. For all food crops, product quality is a fundamental parameter that influences consumers' choices. Gruda et al. [57] listed different types of 
product quality: (1) market value (color, size, consistency); (2) utilization value (shelf life, storability); (3) sensory value (flavor, textural properties); (4) nutritional and health value (desired compounds); (5) ecological value (cultivation method); (6) imaginary value (prestige, image). The first two traits constitute external quality, immediately and easily perceptible by consumers, while points 3 and 4 constitute the internal quality, detectable only by chemical determinations, but extremely important. Among the desired compounds of nutritional and health quality, antioxidant activity and compounds (phenols, vitamins, minerals, etc.) play a key role due to their protective functions against free radical damage by neutralizing and scavenging them [58].

Biostimulant application did not influence lipophilic and hydrophilic antioxidant activity, or total phenols and total ascorbic acid, which were affected by nitrogen dose, except phenols. Indeed, LAA, HAA, and TAA decreased at increased $\mathrm{N}$ levels; these findings are in line with our previous results obtained in baby lettuce treated with three different PBs under four nitrogen regimes $\left(0,10,20\right.$, and $30 \mathrm{~kg} \mathrm{~N}$ ha $\left.^{-1}\right)$, where the LAA, HAA, and TAA decreased with increased $N$ rate [14]. Additionally, Li et al. [59] reported that increasing nitrogen applications decreased total phenolics, the 1,1-diphenyl-2-picrylhydrazyl (DPPH) radical scavenging activity, and ferric-reducing antioxidant power (FRAP) values in two genotypes of leaf mustard.

As expected, the nitrogen fertilization positively affected the SPAD index, which linearly increased with the nitrogen dose, reaching $+17 \%$ in N60 plants compared to N0 plants, more than that reported by Rouphael et al. [60] who highlighted a 4\% SPAD index increase in lettuce at an optimal $\mathrm{N}$ dose with respect to unfertilized lettuce plants. The effect of nitrogen availability on plant state was also highlighted by the increase in green pigment content, especially chlorophyll a and total chlorophyll, which showed the highest value in N60: $+24 \%$ and $+22 \%$ over the mean value of $\mathrm{N} 0$ and N30, respectively. Among the color parameters, only brightness $\left(\mathrm{L}^{*}\right)$ increased at the increased nitrogen level.

Finally, the nitrate content of lettuce leaves was higher in fertilized treatments but without a significant difference between sub-optimal and optimal doses, and the NUE decreased with the increase in nitrogen availability, with $\mathrm{N} 60$ being significantly different from N30. On the other hand, Ronga et al. [2] also reported an NUE decrease in tomato at a high level of nitrogen supply, and a decrease in NUE was also reported for spinach and lamb's lettuce by Di Mola et al. [4]. Therefore, it seems that plants under the highest $\mathrm{N}$ dose show a higher consumption of nitrogen, which is accumulated in leaves without increasing yield.

\section{Conclusions}

The findings of the current research highlighted some important aspects of lettuce management. A supply of $30 \mathrm{~kg} \mathrm{ha}^{-1}$ of nitrogen (sub-optimal) seems to be an ideal dose to reach optimal production without significantly reducing the qualitative aspects of lettuce leaves (LAA, HAA, and TAA). This fertilization regime can be further enhanced by PB application, which further ameliorates the biometric parameters, SPAD index, and leaf colorimetric parameters that dictate the qualitative aspects of food vegetables. Nonetheless, the application of this PB significantly increases the nitrogen use efficiency of lettuce, which falls in the right category of sustainable implementation of biostimulants in modern agriculture. Furthermore, the improvement in nitrogen metabolism caused by the PB is also noted in nitrate accumulation in the leaf tissue, which is not different from non-treated plants. Therefore, although nitrate was not positively modulated by PB application, the current findings are very interesting, and it may be a starting point for further research. Such results can be extrapolated to other leafy vegetables. Yet, further studies are required since the biostimulant effect is not only species dependent but intra-species dependent as well and modulated by a myriad of factors, such as fertilization program, biostimulant concentration, and environmental conditions. 
Author Contributions: Conceptualization, M.M., E.C., I.D.M. and Y.R.; methodology, M.M., E.C., I.D.M. and Y.R.; software, L.O. and C.E.-N.; validation, M.M. and Y.R.; formal analysis, I.D.M. and L.O.; investigation, I.D.M. and C.E.-N.; resources, E.C.; data curation, M.M.; writing-original draft preparation, I.D.M. and L.O.; writing-review and editing, I.D.M., C.E.-N., L.O. and Y.R.; visualization, L.O., E.C. and C.E.-N.; supervision, M.M. and Y.R.; project administration, M.M.; funding acquisition, M.M. All authors have read and agreed to the published version of the manuscript.

Funding: This research received no external funding.

Institutional Review Board Statement: Not applicable.

Informed Consent Statement: Not applicable.

Data Availability Statement: The datasets generated for this study are available on request to the corresponding author.

Acknowledgments: We would like to thank Sabrina Nocerino for her support in laboratory work.

Conflicts of Interest: The authors declare no conflict of interest.

\section{References}

1. Reimer, A.; Doll, J.E.; Basso, B.; Marquart-Pyatt, S.T.; Robertson, G.P.; Stuart, D.; Zhao, J. Moving toward sustainable farming systems: Insights from private and public sector dialogues on nitrogen management. J. Soil Water Conser. 2017, 72, 5A-9A. [CrossRef]

2. Ronga, D.; Parisi, M.; Pentangelo, A.; Mori, M.; Di Mola, I. Effects of nitrogen management on biomass production and dry matter distribution of processing tomato cropped in southern Italy. Agronomy 2019, 9, 855. [CrossRef]

3. Djidonou, D.; Zhao, X.; Simonne, E.H.; Koch, K.E.; Erickson, J.E. Yield, water-, and nitrogen-use efficiency in field-grown, grafted tomatoes. HortScience 2013, 48, 485-492. [CrossRef]

4. Di Mola, I.; Cozzolino, E.; Ottaiano, L.; Nocerino, S.; Rouphael, Y.; Colla, G.; Mori, M. Nitrogen use and uptake efficiency and crop performance of baby spinach (Spinacia oleracea L.) and Lamb's Lettuce (Valerianellalocusta L.) grown under variable sub-optimal N regimes combined with plant-based biostimulant application. Agronomy 2020, 10, 278. [CrossRef]

5. Lassaletta, L.; Billen, G.; Grizzetti, B.; Anglade, J.; Garnier, J. 50 year trends in nitrogen use efficiency of world cropping systems: The relationship between yield and nitrogen input to cropland. Environ. Res. Lett. 2014, 9, 105011. [CrossRef]

6. Sutton, M.A.; Bleeker, A.; Howard, C.M.; Bekunda, M.; Grizzetti, B.; de Vries, W.; van Grinsven, H.J.M.; Abrol, Y.P.; Adhya, T.K.; Billen, G.; et al. Our Nutrient World: The challenge to produce more food and energy with less pollution. Cent. Ecol. Hydrol. 2013, 8, 95-108.

7. Weitzberg, E.; Lundberg, J.O. Novel aspects of dietary nitrate and human health. Annu. Rev. Nutr. 2013, 33, 129-1598. [CrossRef] [PubMed]

8. Tamme, T.; Reinik, M.; Roasto, M. Nitrates and nitrites in vegetables: Occurrence and health risks. Bioact. Foods Promot. Health 2010, 307-321. [CrossRef]

9. Aires, A.; Carvalho, R.; Rosa, E.A.S.; Saavedra, M.J. Effects of agriculture production systems on nitrate and nitrite accumulation on baby-leaf salads. Food Sci. Nutr. 2013, 1, 3-7. [CrossRef]

10. Rouphael, Y.; Spíchal, L.; Panzarová, K.; Casa, R.; Colla, G. High-throughput plant phenotyping for developing novel biostimulants: From lab to field or from field to lab? Front. Plant Sci. 2018, 9, 1197. [CrossRef]

11. Ertani, A.; Cavani, L.; Pizzeghello, D.; Brandellero, E.; Altissimo, A.; Ciavatta, C.; Nardi, S. Biostimulant activity of two protein hydrolyzates in the growth and nitrogen metabolism of maize seedlings. J. Plant Nutr. Soil Sci. 2009, 172, 237-244. [CrossRef]

12. Carillo, P.; Colla, G.; Fusco, G.M.; Dell'Aversana, E.; El-Nakhel, C.; Giordano, M.; Pannico, A.; Cozzolino, E.; Mori, M.; Reynaud, H.; et al. Morphological and physiological responses induced by protein hydrolysate based biostimulant and nitrogen rates in greenhouse spinach. Agronomy 2019, 9, 450. [CrossRef]

13. Caruso, G.; De Pascale, S.; Cozzolino, E.; Cuciniello, A.; Cenvinzo, V.; Bonini, P.; Colla, G.; Rouphael, Y. Yield and nutritional quality of Vesuvian Piennolo tomato PDO as affected by farming system and biostimulant application. Agronomy 2019, 9, 505. [CrossRef]

14. Di Mola, I.; Cozzolino, E.; Ottaiano, L.; Giordano, M.; Rouphael, Y.; Colla, G.; Mori, M. Effect of vegetal- and seaweed extractbased biostimulants on agronomical and leaf quality traits of plastic tunnel-grown baby lettuce under four regimes of nitrogen fertilization. Agronomy 2019, 9, 571. [CrossRef]

15. Di Mola, I.; Ottaiano, L.; Cozzolino, E.; Senatore, M.; Giordano, M.; El-Nakhel, C.; Sacco, A.; Rouphael, Y.; Colla, G.; Mori, M. Plant-Based Biostimulants Influence the Agronomical, Physiological, and Qualitative Responses of Baby Rocket Leaves under Diverse Nitrogen Conditions. Plants 2019, 8, 522. [CrossRef] [PubMed]

16. Ertani, A.; Schiavon, M.; Muscolo, A.; Nardi, S. Alfalfa plant-derived biostimulant stimulate short-term growth of salt stressed Zea mays L. plants. Plant Soil 2013, 64, 145-158. [CrossRef]

17. Di Mola, I.; Conti, S.; Cozzolino, E.; Melchionna, G.; Ottaiano, L.; Testa, A.; Mori, M. Plant-Based Protein Hydrolysate Improves Salinity Tolerance in Hemp: Agronomical and Physiological Aspects. Agronomy 2021, 11, 342. [CrossRef] 
18. Rouphael, Y.; De Micco, V.; Arena, C.; Raimondi, G.; Colla, G.; De Pascale, S. Effect of Ecklonia maxima seaweed extract on yield, mineral composition, gas exchange and leaf anatomy of zucchini squash grown under saline conditions. J. Appl. Phycol. 2017, 29, 459-470. [CrossRef]

19. Botta, A. Enhancing plant tolerance to temperature stress with amino acids: An approach to their mode of action. Acta Hortic. 2013, 1009, 29-35. [CrossRef]

20. Calvo, P.; Nelson, L.; Kloepper, J.W. Agricultural uses of plant biostimulants. Plant Soil 2014, 383, 3-41. [CrossRef]

21. Colla, G.; Hoagland, L.; Ruzzi, M.; Cardarelli, M.; Bonini, P.; Canaguier, R.; Rouphael, Y. Biostimulant action of protein hydrolysates: Unraveling their effects on plant physiology and microbiome. Front. Plant Sci. 2017, 8, 2202. [CrossRef]

22. Cozzolino, E.; Giordano, M.; Fiorentino, N.; El-Nakhel, C.; Pannico, A.; Di Mola, I.; Rouphael, Y. Appraisal of biodegradable mulching films and vegetal-derived biostimulant application as eco-sustainable practices for enhancing lettuce crop performance and nutritive value. Agronomy 2020, 10, 427. [CrossRef]

23. Rouphael, Y.; Colla, G. Synergistic biostimulatory action: Designing the next generation of plant biostimulants for sustainable agriculture. Front. Plant Sci. 2018, 9, 1655. [CrossRef]

24. Stima Delle Superfici E Produzioni Delle Coltivazioni Agrarie, Floricole E Delle Piante Intere Da Vaso. Available online: http:/ / dati.istat.it/Index.aspx?QueryId=33703\# (accessed on 12 April 2021).

25. Kim, M.J.; Moon, Y.; Tou, J.C.; Mou, B.; Waterland, N.L. Nutritional value, bioactive compounds and health beneficts of lettuce (Lactuca sativa L.). J. Food Comp. Anal. 2016, 49, 19-34. [CrossRef]

26. Baslam, M.; Idoia, G.; Nieves, G. The arbuscular mycorrhizal symbiosis can overcome reductions inyield and nutritional quality in greenhouse-lettuces cultivated at inappropriate growing seasons. Sci. Hortic. 2013, 164, 145-154. [CrossRef]

27. Sofo, A.; Lundegårdh, B.; Mårtensson, A.; Manfra, M.; Pepe, G.; Sommella, E.; Scopa, A. Different agronomic and fertilization systems affect polyphenolic profile, antioxidant capacity and mineral composition of lettuce. Sci. Hort. 2016, 204, 106-115. [CrossRef]

28. Perveen, S.; Iqbal, M.; Parveen, A.; Akram, M.S.; Shahbaz, M.; Akber, S.; Mehboob, A. Exogenous triacontanol-mediated increase in phenolics, proline, activity of nitrate reductase, and shoot $\mathrm{k}+$ confers salt tolerance in maize (Zea mays L.). Braz. J. Bot. 2017, 40, 1-11. [CrossRef]

29. Singh, M.; Khan, M.M.A.; Moinuddin, I.M.; Naeem, M. Augmentation of nutraceuticals, productivity and quality of ginger (Zingiber officinale Rosc.) through triacontanol application. Plant Biosyst. 2012, 146, 106-113. [CrossRef]

30. Ries, S.K.; Richman, T.L.; Wert, V.F. Growth and yield of crops treated with triacontanol. J. Am. Soc. Hort. Sci. 1978, 103, 361-364.

31. Naeem, M.; Khan, M.M.A.; Moinuddin, I.M.; Aftab, T. Triacontanol-mediated regulation of growth and other physiological attributes, active constituents and yield of Mentha arvensis L. Plant Growth Regul. 2011, 65, 195-206. [CrossRef]

32. Grzegorczyk, I.; Bilichowski, I.; Mikicuik-Olasik, E.; Wysokinska, H. The effect of triacontanol on shoot multiplication and production of antioxidant compounds in shoot cultures of Salvia officinalis L. Acta Soc. Bot. Pol. 2006, 75, 11-15. [CrossRef]

33. Grzegorczyk, I.; Bilichowski, I.; Mikicuik-Olasik, E.; Wysokinska, H. In vitro cultures of Salvia officinalis L. as a source of antioxidant compounds. Acta Soc. Bot. Pol. 2005, 74, 17-21. [CrossRef]

34. ILSA. Available online: https://www.ilsagroup.com/en/prodotti/prodotto/87/ilsastim.htm (accessed on 5 December 2019).

35. Kumaravelu, G.; Livingstone, V.D.; Ramanujam, M.P. Triacontanol-induced changes in the growth, photosynthetic pigments, cell metabolites, flowering and yield of green gram. Biol. Plantarum 2000, 43, 287-290. [CrossRef]

36. Chen, S.K.; Subler, S.; Edwards, C.A. Effects of agricultural biostimulants on soil microbial activity and nitrogen dynamics. Appl. Soil Ecol. 2002, 19, 249-259. [CrossRef]

37. Islam, S.; Zaid, A.; Mohammad, F. Role of triacontanol in counteracting the ill effects of salinity in plants: A review. J. Plant Growth Regul. 2021, 40,1-10. [CrossRef]

38. Lichtenhaler, H.K.; Wellburn, A.R. Determinations of total carotenoids and chlorophylls a and b of leafextracts in different solvents. Biochem. Soc. Trans. 1983, 11, 591-592. [CrossRef]

39. Fogliano, V.; Verde, V.; Randazzo, G.; Ritieni, A. Method for measuring antioxidant activity and its application to monitoring the antioxidant capacity of wines. J. Agric. Food Chem. 1999, 47, 1035-1040. [CrossRef] [PubMed]

40. Re, R.; Pellegrini, N.; Proteggente, A.; Pannala, A.; Yang, M.; Rice-Evans, C. Antioxidant activity applying an improved ABTS radical cation decolorization assay. Free. Radic. Biol. Med. 1999, 26, 1231-1237. [CrossRef]

41. Singleton, V.L.; Orthofer, R.; Lamuela-Raventos, R.M. Analysis of Total Phenols and Other Oxidation Substrates and Antioxidants by Means of Folin-Ciocalteu Reagent. In Methods in Enzymology; Academic Press: Cambridge, MA, USA, 1999; Volume 299, pp. 152-178.

42. Kampfenkel, K.; Montagu, M.V.; Inzè, D. Extraction and determination of ascorbate and dehydroascorbate from plant tissue. Ann. Rev. Biochem. 1995, 225, 165-167. [CrossRef] [PubMed]

43. Kopta, T.; Pavlikova, M.; Sękara, A.; Pokluda, R.; Maršálek, B. Effect of bacterial-algal biostimulant on the yield and internal quality of lettuce (Lactuca sativa L.) produced for spring and summer crop. Not. Bot. Horti Agrobot. 2018, 46, 615-621. [CrossRef]

44. Cristofano, F.; El-Nakhel, C.; Pannico, A.; Giordano, M.; Colla, G.; Rouphael, Y. Foliar and root applications of vegetal-derived protein hydrolysates differentially enhance the yield and qualitative attributes of two lettuce cultivars grown in floating system. Agronomy 2021, 11, 1194. [CrossRef]

45. Khan, S.; Yu, H.; Li, Q.; Gao, Y.; Sallam, B.N.; Wang, H.; Jiang, W. Exogenous application of amino acids improves the growth and yield of lettuce by enhancing photosynthetic assimilation and nutrient availability. Agronomy 2019, 9, 266. [CrossRef] 
46. Kapitsimadi, C.; Gerasopoulos, D.; Olympios, C.; Passam, H. Effect of a long chain aliphatic alcohol (triacontanol) on growth and yield of different horticultural crops. Acta Hort. 1995, 379, 237-243. [CrossRef]

47. Knowles, N.R.; Ries, S.K. Rapid growth and apparent total nitrogen increases in rice and corn plants following applications of triacontanol. Plant Physiol. 1981, 68, 1279-1284. [CrossRef]

48. Schiavon, M.; Ertani, A.; Nardi, S. Effects of an alfalfa protein hydrolysate on the gene expression and activity of enzymes of TCA cycle and N metabolism in Zea mays L. J. Agr. Food Chem. 2008, 56, 11800-11808. [CrossRef]

49. European Community. Reg. $\mathrm{n}^{\circ} 1258$ of 2 December 2011. Off. J. Eur. Union. 2011, L 320, $15-17$.

50. Di Mola, I.; Rouphael, Y.; Colla, G.; Fagnano, M.; Paradiso, R.; Mori, M. Morphophysiological traits and nitrate content of greenhouse lettuce as affected by irrigation with saline water. HortScience 2017, 52, 1716-1721. [CrossRef]

51. Di Mola, I.; Rouphael, Y.; Ottaiano, L.; Duri, L.G.; Mori, M.; De Pascale, S. Assessing the effects of salinity on yield, leaf gas exchange and nutritional quality of spring greenhouse lettuce. International Symposium on New Technologies for Environment Control, Energy-Saving and Crop Production in Greenhouse and Plant. Acta Hortic. 2018, 1227, 479-484. [CrossRef]

52. Muthuchelian, K.; Murugan, C.; Harigovindan, R.; Nedunchezhian, N.; Kulandaivelu, G. Effect of triacontanol in flooded Erythrina variegata seedlings. 2. Changes in $\left(\mathrm{CO}_{2}\right)$-c-14 fixation, and ribulose-1, 5-b-isophosphate carboxylase, photosystem and nitrate reductase activities. Photosynthetica 1997, 30, 407-413.

53. Tischner, R. Nitrate uptake and reduction in higher and lower plants. Plant Cell EnViron. 2000, 23, 1005-1024. [CrossRef]

54. Hirel, B.; Bertin, P.; Quillere', I.; Bourdoncle, W.; Attagnant, C.; Dellay, C.; Gouy, A.; Cadiou, S.; Retailliau, C.; Falque, M.; et al. Towards a better understanding of the genetic and physiological basis for nitrogen use efficiency in maize. Plant Physiol. 2001, 125, 1258-1270. [CrossRef]

55. Coruzzi, G.; Bush, D.R. Nitrogen and C nutrient and metabolite signaling in plants. Plant Physiol. 2001, 125, 61-64. [CrossRef] [PubMed]

56. Islam, S.; Mohammad, F. Triacontanol as a dynamic growth regulator for plants under diverse environmental conditions. Phy. Molecr. Biol. Plants 2020, 26, 871-883. [CrossRef] [PubMed]

57. Gruda, N. Impact of environmental factors on product quality of greenhouse vegetables for fresh consumption. Crc. Crit. Rev. Plant Sci. 2005, 24, 227-247. [CrossRef]

58. Dhalaria, R.; Verma, R.; Kumar, D.; Puri, S.; Tapwal, A.; Kumar, V.; Kuca, K. Bioactive Compounds of Edible Fruits with Their Anti-Aging Properties: A Comprehensive Review to Prolong Human Life. Antioxidants 2020, 9, 1123. [CrossRef]

59. Li, J.; Zhu, Z.; Gerendás, J. Effects of nitrogen and sulfur on total phenolics and antioxidant activity in two genotypes of leaf mustard. J. Plant Nutr. 2008, 31, 1642-1655. [CrossRef]

60. Rouphael, Y.; Carillo, P.; Colla, G.; Fiorentino, N.; Sabatino, L.; El-Nakhel, C.; Woo, S.L. Appraisal of combined applications of Trichoderma virens and a biopolymer-based biostimulant on lettuce agronomical, physiological, and qualitative properties under variable N regimes. Agronomy 2020, 10, 196. [CrossRef] 